\title{
Effect of aluminum on the growth of the in vitro culture tissues of the date palm (Phoenix dactylifera L.) cv. Um-Aldehin
}

\author{
Ahmed Madi Waheed Al-Mayahi* \\ Date Palm Research Centre, University of Basrah, Basrah, Iraq
}

\begin{abstract}
AL-MaYahi, A.M.W., 2019. Effect of aluminium on the growth of the in vitro culture tissues of the date palm (Phoenix dactylifera L.) cv. Um-Adelhin. Folia Oecologica, 46: 164-169.

This study was carried out to evaluate the effect of different concentrations of aluminum: (25, 50 and 100 mg $\mathrm{l}^{-1}$ of aluminum chloride $\mathrm{AlCl}_{3} .6 \mathrm{H}_{2} \mathrm{O}$ ) on the enhancement of shoot multiplication, phytochemicals, as well as, antioxidant enzyme activity of in vitro cultures of the date palm cv. Um-Aldehin. The addition of aluminum in a concentration of $50 \mathrm{mg}^{-1}$ to the medium exhibited most effects on shoots regeneration and this substance also increased the number of shoots per a jar ( $73.34 \%$ and 8.2 shoots/jar, respectively), compared to the other concentrations, including the control treatment. A biochemical analysis of date palm shoots revealed that the high concentration of aluminum chloride $\left(100 \mathrm{mg} \mathrm{l}^{-1}\right)$ led to a significant accumulation of the total proline content, and to a high activity of ascorbate peroxidase, as well as a significant reduction in nitrogen, phosphorus, calcium, magnesium and chlorophyll, compared to the concentration of $50 \mathrm{mg}^{-1}$ for which there were recorded the highest contents of the mentioned elements, together with the highest content of chlorophyll in leaves.
\end{abstract}

Keywords

$\mathrm{AlCl}_{3}$, ascorbate peroxidase, chlorophyll, proline, shoot regeneration

\section{Introduction}

Date palm (Phoenix dactylifera L.) belonging to the monocotyledonous family Arecaceae is an economically important tree species. The exact origin of the date palm is unknown, but according to the archaeological evidence from the ancient Mesopotamia, it is believed that this plant originated in the southern region of the present-day Iraq, at least 6,000 years ago (ChaO and Krueger, 2007; ALKhalifaH and Manickavsagan, 2012). The traditional method for the date palm propagation is through offshoots, but many factors may hinder their application. Therefore, the tissue culture technique can be used as another method for the date palm propagation. Micro-propagation of date palm cultivars is a promising way to apply them successfully on the commercial scale (JASIM et al., 2009;
Al-MaYAHI et al., 2010). The main reasons for using this method are: virus-free planting material possible to obtain, and to multiply these plants quickly throughout the year irrespective of the season and weather. During vegetative propagation by offshoots, many diseases are often spread, which also results in a limited number of offshoots (GuEYE et al., 2009). Plant tissues and organs are cultured on artificial culture media providing the nutrients essential for growth and development.

Tissue cultures were used in many studies on plant response to metal ions, with conclusions that the success of plant propagation by tissue cultures was highly influenced by the composition of the culture medium used (AL-MAYAHI, 2012 and 2014). The data showed that $\mathrm{AlCl}_{3}$ treatments induced and propelled differentiation of friable callus explants of the date palm cv. Sewi (ZAYED et

*Corresponding author:

e-mail: hng_1988@yahoo.com 
al., 2019). High concentrations of Al caused the inhibition of cells elongation and their evolution. It also interfered with the absorption and transport of many nutrients, such as $\mathrm{Ca}, \mathrm{Mg}, \mathrm{K}, \mathrm{P}$ and Fe (EzaKi, 2004; Rout et al., 2001). The plant cells possess highly efficient defense systems for response to abiotic and biotic stress. Some elements, aluminum included, have been identified necessary and useful for some plant species, but this fact still requires a closer specification of its importance on a larger scale. The present study is an attempt to understand the in vitro effects of aluminum on organogenesis expressed as induction of adventitious buds from callus, multiplication shoots and some biochemical changes of the date palm cv. UmAldehin.

\section{Materials and methods}

Callus was separated and cultured on a MS basal medium (Murashige and Skoog, 1962) with an addition of $0.5 \mathrm{mg}$ $1^{-1}$ naphthalene acetic acid (NAA), $0.5 \mathrm{mg}^{-1}$ 6-benzyladenine (BA), $0.5 \mathrm{mg} \mathrm{l}^{-1} \mathrm{~N}^{6}$-furfuryladenine "kinetin" and $0.5 \mathrm{~g} \mathrm{l}^{-1}$ activated charcoal (AL-MAYAHI, 2016a). Different concentrations of $\mathrm{Al}$ were used: 25,50 , and $100 \mathrm{mg} \mathrm{l}^{-1}$ of aluminum chloride $\mathrm{AlCl}_{3} \cdot 6 \mathrm{H}_{2} \mathrm{O}$. Al was sterilized separately and added to the rest of the medium before pouring it in jars, together with the control treatment (without Al). All the cultures were incubated at $27 \pm 2{ }^{\circ} \mathrm{C}$ and irradiated for $16 \mathrm{~h}$ with a diffuse light provided by daylight fluorescent lamps. The results of the experiments regarding the percentage of shoot regeneration and shoot number per a jar were evaluated 12 weeks after the inoculation of callus on the media. There were fifteen replicates of each treatment.

\section{Effect of aluminum on some growth criteria}

The growth criteria as response of callus (100 mg weight) for shoot formation (\%) and the number of shoots per a jar were recorded after 12 weeks from the callus culture application.

\section{Biochemical and physiological parameters determina- tion \\ Estimation of macronutrients for in vitro shoots grow- ing}

Contents of nitrogen, phosphorus, potassium, calcium, magnesium, and sodium in shoots of date palm cv. Um-Aldehin were analyzed according to the method described by Cresser and Parsons (1979). The shoots were dried and subsequently washed with rinsed distilled water, re-dried and homogenized. After sieving the shoot tissues, they were prepared for analyses by the method of wet digestion using a combination of sulfuric acid (69\%) and perchloric acid $(62 \%)$ under heating for one hour, then, the digested solution was transferred into volumetric flasks with a volume of $50 \mathrm{~cm}^{3}$, and the volumes were completed in size with deionized water. Chemical analyzes of nutrients were performed using the following methods: The $\mathrm{N}$ content in shoot tissues was determined by the Kjeldahl method according to PAGE et al. (1982); phosphorus was determined by spectrophotometer at $880 \mathrm{~nm}$, according to MURPHY and Riley (1962). K, Ca, Mg, and $\mathrm{Na}$ was measured by atomic absorption spectrometry, according to method described by BLACK (1965).

\section{Assay of antioxidant enzyme activities}

Ascorbate peroxidase (APX; EC 1.11.1.11) was measured from $\mathrm{Al}$ treated shoots, as well as non-treated shoots (control treatment) spectrophotometrically at $290 \mathrm{~nm}, 50 \mathrm{mM}$ potassium phosphate buffer $(\mathrm{pH} 7.0), 0.5 \mathrm{mM}$ ascorbic acid, $0.1 \mathrm{mM}$ hydrogen peroxide, and $0.1 \mathrm{ml}$ of enzyme extract in a total volume of $1 \mathrm{ml}$. The absorption coefficient was $2.8 \mathrm{mM}^{-1} \mathrm{~cm}^{-1}$, after 10 weeks of culturing in different media (NAKANO and AsADA, 1981). The absorption coefficient was $2.8 \mathrm{mM}^{-1} \mathrm{~cm}^{-1}$. One unit of APX was defined as $1 \mathrm{mmol} \mathrm{ml}^{-1}$ ascorbate oxidized $\mathrm{min}^{-1}$ (HossIAN et al., 2006).

\section{Determination of proline content}

The amount of proline in date palm shoots was determined according to the method described by BATES et al. (1973), where the proline concentration was calculated based on a standard curve and was expressed as $\mu \mathrm{mol}$ proline $\mathrm{g}^{-1} \mathrm{FW}$.

\section{Assessment of chlorophyll content}

The total chlorophyll content in the leaves was estimated according to the method described by (PorRA, 2002).

\section{Statistical analysis}

All the data were statistically analyzed by one way analysis of variance (ANOVA), and with the least significant difference (LSD) method used to test the difference between the treatments, with $p \leq 0.05$ considered as statistically insignificant. Statistical analyses were performed with a SPSS packet software.

\section{Results}

\section{Growth parameters}

Table 1 summarizes the data of the growth and development of callus tissue of date palm cv. Um-Aldehin using three $\mathrm{Al}$ concentrations as well as the control treatment. The cultures grown at $\mathrm{Al}\left(50 \mathrm{mg} \mathrm{l}^{-1}\right)$ showed better result in amount $(73.34 \%)$ of callus producing shoots and average shoots formation ( 8.20 shoots/jar) compared with the cultures grown at $\mathrm{Al}$ ( 0 "control treatment" and $\left.25 \mathrm{mg} \mathrm{l}^{-1}\right)$, which were $53.34 \%$, 5.6 shoots, and $60.00 \%$, 6.7 shoots, respectively. While the increasing Al levels obtained the lowest response percentage $(40.0 \%)$ of callus producing shoots and average shoots formation ( 3.8 shoots/jar) in the growth medium to $100 \mathrm{mg} \mathrm{l}^{-1}$ (Fig. 1). 

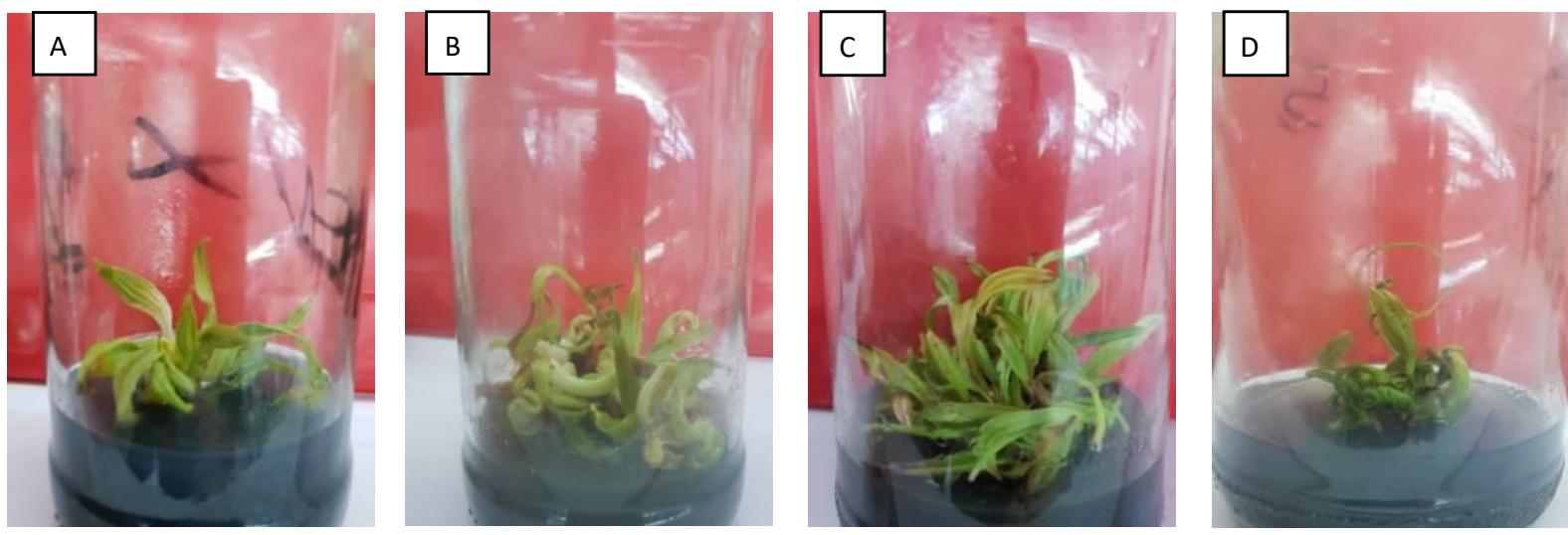

Fig.1. Effect of aluminum on in vitro shoot multiplication in date palm cv. Um-Aldehin after 12 week-treatment: A) 0.0 “Control treatment", B) 25, C) 50, D) $100\left(\mathrm{mg} \mathrm{l}^{-1}\right)$.

Table 1. Effect of different aluminum amounts on the response (percentage) of callus converted for shoot formation and the number of shoots/jar, after 12 weeks from the culturing for date palm $(\mathrm{n}=15)$

\begin{tabular}{ccc}
\hline $\begin{array}{c}\text { Treatments } \\
\left(\mathrm{mg} \mathrm{l}^{-1}\right)\end{array}$ & $\begin{array}{c}\text { Response of } \\
\text { callus }(100 \mathrm{mg} \\
\text { weight }) \text { for } \\
\text { shoot } \\
\text { formation }\end{array}$ & $\begin{array}{c}\text { No. of } \\
\text { shoots } / \text { jar }\end{array}$ \\
\hline 0.0 Control & $53.34 \mathrm{~b}^{*}$ & $5.6 \mathrm{~b}$ \\
25 & $60.00 \mathrm{bc}$ & $6.7 \mathrm{~b}$ \\
50 & $73.34 \mathrm{a}$ & $8.2 \mathrm{a}$ \\
100 & $40.00 \mathrm{c}$ & $3.8 \mathrm{c}$ \\
\hline
\end{tabular}

*Values followed by the same letter vertically are not significantly different at $\mathrm{p}<0.05$.

According to the results obtained, the $\mathrm{Al}$ treatment led to some of the most significant effects as for macronutrient accumulation in the shoot tissues of the date palm. The shoots grown in the medium supplemented with $\mathrm{Al}$ at $50 \mathrm{mg} \mathrm{l}^{-1}$ exhibited a significant increase in their content of elements: N (5.113\%), P (2.907 mg g $\left.{ }^{-1} \mathrm{DW}\right), \mathrm{K}$ (4.475 mg $\left.\mathrm{g}^{-1} \mathrm{DW}\right), \mathrm{Ca}\left(17.690 \mathrm{mg} \mathrm{g}^{-1} \mathrm{DW}\right)$ and $\mathrm{Mg}\left(14.024 \mathrm{mg} \mathrm{g}^{-1}\right.$ DW), compared to the other treatments (Table 2). On the other hand, increasing $\mathrm{Al}$ concentrations in the culture medium to $100 \mathrm{mg} \mathrm{l}^{-1}$ decreased the $\mathrm{N}, \mathrm{P}, \mathrm{K}, \mathrm{Ca}$, and $\mathrm{Mg}$, in shoots of date palm cv. Um-Aldehin. The only exception was K content that remained significantly unchanged with increasing of $\mathrm{Al}$ concentrations in the culture medium compared to the control treatment (Table 2).

\section{The activity of ascorbate peroxidase (APX)}

The results in Fig. 2 show changes in ascorbate peroxidase (APX; EC 1.11.1.11) enzyme activity under different concentrations of $\mathrm{AlCl}_{3}$. The APX enzyme activity increased linearly with increasing Al level from $0-100 \mathrm{mg} \mathrm{l}^{-1}$. The highest level of APX was recorded in the shoots cultured in the medium supplied with a high concentration of aluminum $100 \mathrm{mg} \mathrm{l}^{-1}$, while the least activity of APX was achieved in the control treatment after 12 weeks of culture exposed in the different media.

\section{Changes in proline}

The results given in Fig. 3 indicate that increasing $\mathrm{AlCl}_{3}$ levels in the media $(0-100) \mathrm{mg} \mathrm{l}^{-1}$, increased the proline levels in the shoots significantly $(\mathrm{p}<0.05)$, while the minimum proline content was detected at the control treatment.

\section{Changes in chlorophyll}

Chlorophyll a, b, and total chlorophyll content of the shoots increased with the increasing $\mathrm{Al}$ concentrations up to the optimal level $\left(50 \mathrm{mg} \mathrm{l}^{-1} \mathrm{AlCl}_{3}\right)$, them there fol-

Table 2. The effect of aluminum on the macronutrient content in the shoots of date palm cv. Um-Aldehin in vitro*

\begin{tabular}{cccccc}
\hline Treatments $\left(\mathrm{mg} \mathrm{l}^{-1}\right)$ & $\begin{array}{c}\mathrm{N} \\
(\%)\end{array}$ & $\begin{array}{c}\mathrm{P} \\
\left(\mathrm{mg} \mathrm{g}^{-1} \mathrm{DW}\right)\end{array}$ & $\begin{array}{c}\mathrm{K} \\
\left(\mathrm{mg} \mathrm{g}^{-1} \mathrm{DW}\right)\end{array}$ & $\begin{array}{c}\mathrm{Ca} \\
\left(\mathrm{mg} \mathrm{g}^{-1} \mathrm{DW}\right)\end{array}$ & $\begin{array}{c}\mathrm{Mg} \\
\left(\mathrm{mg} \mathrm{g}^{-1} \mathrm{DW}\right)\end{array}$ \\
\hline 0.0 control & $4.235 \mathrm{~b}^{*}$ & $2.154 \mathrm{~b}$ & $3.945 \mathrm{~b}$ & $15.853 \mathrm{~b}$ & $12.874 \mathrm{~b}$ \\
25 & $4.380 \mathrm{~b}$ & $2.218 \mathrm{~b}$ & $4.158 \mathrm{~b}$ & $16.124 \mathrm{~b}$ & $13.018 \mathrm{~b}$ \\
50 & $5.113 \mathrm{a}$ & $2.907 \mathrm{a}$ & $4.475 \mathrm{a}$ & $17.690 \mathrm{a}$ & $14.024 \mathrm{a}$ \\
100 & $3.433 \mathrm{c}$ & $1.014 \mathrm{c}$ & $3.873 \mathrm{~b}$ & $15.078 \mathrm{c}$ & $11.938 \mathrm{c}$ \\
\hline
\end{tabular}

*Values followed by the same letter vertically are not significantly different at $\mathrm{p}<0.05$. 


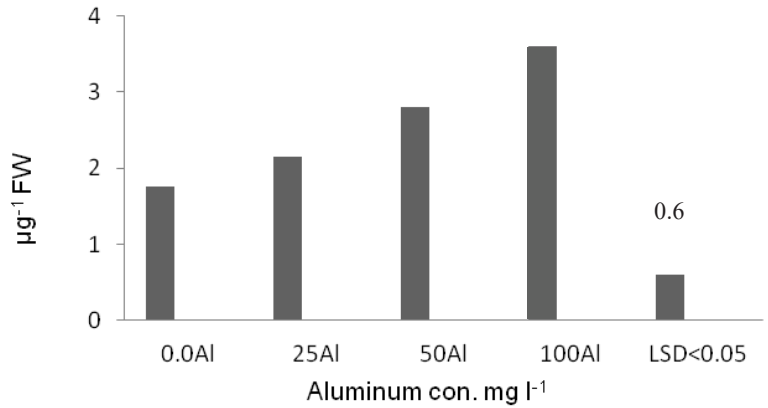

Fig. 2. Effect of different aluminum concentrations on ascorbate peroxidase activity.

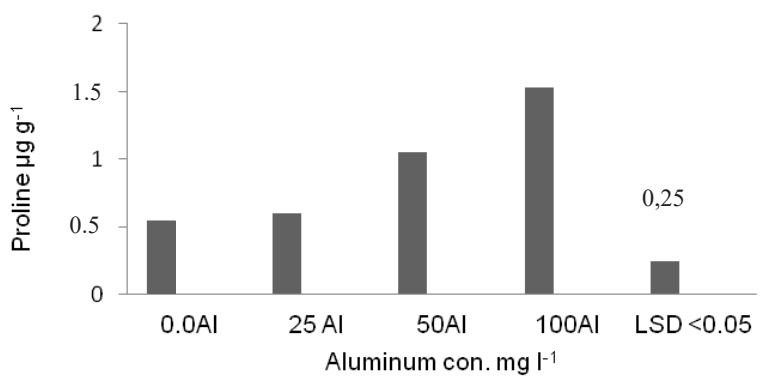

Fig. 3. Effect of different aluminum concentrations on proline content.

lowed a decrease, with the minimum chlorophylls content found at the highest concentrations used $\left(100 \mathrm{mg} \mathrm{l}^{-1} \mathrm{AlCl}_{3}\right)$ (Table 3).

Table 3. Effect of different concentrations of aluminum on the content of chlorophylls a, b, and total chl in the date palm cv. Um-Aldehin in vitro

\begin{tabular}{cccc}
\hline $\begin{array}{c}\text { Treatments } \\
\left(\mathrm{mg} \mathrm{l}^{-1}\right)\end{array}$ & Chl a & Chl b & Total Chl \\
\hline 0.0 control & $0.67 \mathrm{~b}^{*}$ & $0.21 \mathrm{c}$ & $0.88 \mathrm{c}$ \\
25 & $0.72 \mathrm{~b}$ & $0.25 \mathrm{~b}$ & $0.97 \mathrm{~b}$ \\
50 & $1.04 \mathrm{a}$ & $0.037 \mathrm{a}$ & $1.41 \mathrm{a}$ \\
100 & $0.51 \mathrm{c}$ & $0.18 \mathrm{~d}$ & $0.69 \mathrm{~d}$ \\
\hline
\end{tabular}

*Values followed by the same letter vertically are not significantly different at $\mathrm{p}<0.05$.

\section{Discussion}

The tissue culture technique we used helped in solving many challenging problems traditionally difficult to tackle by other known methods. The application of Al (25 and 50 $\mathrm{mg}^{-1}$ ) induced a growth enhancement and regeneration of shoots, which was accompanied by increased mineral concentrations in the shoots. This suggests that the Al concentration in plant tissues is related to the growth-induced effect of Al. The inhibition of shoot growth was present at the high concentration of aluminum $\left(100 \mathrm{mg} \mathrm{l}^{-1}\right)$, probably due to a disturbance of the cell division in the meristematic zone. It has been briefly described that the addition of low concentrations of aluminum increases the plants growth (TAIZ and ZeIger, 2009). The elements N, P, K, Ca, and $\mathrm{Mg}$ have significantly increased with the increase of the aluminum concentration to the optimum concentration (50 $\mathrm{mg} \mathrm{l}^{-1}$ ), then the content of these elements decreased with the increase of the aluminum concentration to 100 $\mathrm{mg} \mathrm{l}^{-1}$. One of the effects of high concentrations of aluminum in plants is the interference in absorption of minerals, especially phosphorus (MARSCNER, 1995). The aluminum can decrease the absorption of $\mathrm{K}$ by competitive discourage (Malavolta et al., 1997). It has been reported that the potassium deficiency, stimulated by aluminum, affects nitrogen metabolism by inducing the accumulation of putrescine (BAsso et al., 2007), whose diamine interacts with phospholipids, and decreases the fluidity of the plasmatic membrane. The reduction of nutrient uptake for date palm shoots grown with $\mathrm{Al}$ corroborates with the results of a previous report carried out on the bananas (RUFYIKIRI, 2000). Al effects on nutrient absorption can also affect the water uptake by alteration of the plant metabolism. The reduction in percentage response of callus to regeneration of shoots and number of shoots generated may be attributed to limited absorption of nutrients, such as $\mathrm{Ca}$ and $\mathrm{Mg}$, at a high concentration of $\mathrm{Al}$. Our results agree with Meriǹo-GerGichevich et al. (2010), who found that the reduction in shoot and root dry weight was accompanied with limited absorption of nutrients, such as $\mathrm{Ca}$ and $\mathrm{Mg}$, caused by Al. RiBEIRo el al. (2013) reported that the $\mathrm{N}, \mathrm{P}, \mathrm{K}, \mathrm{Ca}$, and $\mathrm{Mg}$ decreased in two genotypes of cocoa with Al-treatments. RUFYIKIRI et al. (2000) mentioned that the $\mathrm{Al}$ inhibited the absorption of elements $(\mathrm{Ca}, \mathrm{Mg}$, $\mathrm{K}, \mathrm{P}$ ) especially Mg. Amaral et al. (2013) reported that the aluminum stimulates the potassium concentrations in the $S$. macrocephala. The reduction of growth under high stress may relate to the decrease in nutritive elements uptake (YousEFI et al., 2017). Our results are accord with the results reached JEMO et al. (2007), concerning the P content for Al-treated Vignaun guiculata, whose P accumulation was significantly reduced. The results of our study agree with RiBEIRO et al. (2013) who mentioned that the increase the concentration of aluminum reduced the content of metal elements in the plant parts. $\mathrm{Al}$ associates with oxygen donor molecules and accelerates production of reactive oxygen species (ROS). These ROS cause oxidative damage to cellular organisms and bimolecular and thus lead to several metabolic modifications (MA, 2007). The ability of a plant to improve its capacity to remove ROS is an essential factor in the mechanism of oxidative stress tolerance. It was observed that the antioxidant capacity of the date palm shoots varies according to the $\mathrm{Al}$ treatment applied. The Al effect suggests that the non-enzymatic antioxidant defense mechanism is differentially activated according to $\mathrm{Al}$ concentration, which could be an indication that the effective antioxidant answer occurs at high concentrations of $\mathrm{Al}$, as was the case of $100 \mathrm{mg} \mathrm{l}^{-1}$ Al treatment. Plants have effective systems to crush active 
oxygen species that protect them from destructive oxidation reactions (MunNĒ-Bosch et al., 2001). Antioxidant enzymes are the main components of defense mechanisms protecting cells from damage. Plants with high levels of antioxidants are more resistant to oxidative damage (KoCA et al., 2007). From the present study, it has been concluded that the stimulation in proline accumulation may reflect the overcoming the stress generated by aluminum in shoots of date palm in vitro. The increase in proline content due to $\mathrm{Al}$ concentrations has been reported by AmaraL et al. (2013). Proline accumulation helps to stabilize sub-cellular structures (proteins and membranes), free radical scavengers, and defending cellular redox potential under stress conditions (Ashraf and Foolad, 2007). Therefore, the accumulation of this amino acid may be a part of general adaptation to stress conditions after being observed as a response to several stresses, including exposure to Al (SIRIPORNADULSIL et al. 2002). Proline functions acting as indicators of prevention, prevent stress-caused damages. Also, many studies supported the correlation between proline synthesis and improved resistance. Proline accumulation in cells protects them against many harmful effects including the high contents of mineral elements. Many reports suggest a positive relationship between proline accumulation and plant stress (AL-MAYAHI, 2015, 2016b, c). In current experiments, the activity of APX was synchronized with an increase of aluminum levels, therefore, controlling the level of $\mathrm{H}_{2} \mathrm{O}_{2}$. The increase in APX activity can be due to stress caused by changes in the media composition, where $\mathrm{Al}$ induces a stress response (SIRIPORNADULSIL et al. 2002, VARDAR et al., 2006). The accumulation of excessive quantities of heavy metals in plant tissues of causes changes in physiological processes, including the biosynthesis of chlorophyll (Hussian et al., 2010; AL-MaYAHI, 2014). Chlorophyll a fluorescence has been described by KALAJI et al. (2016) as an important tool for monitoring the physiological state of plants growing under different environmental stress conditions. It has been found that different stress has harmful effects on photosynthesis process rate in many plant species (Uhrin et al., 2018). RiBEIRo et al. (2013), Ribeiro et al. (2013) reported that increasing $\mathrm{Al}$ levels decreased photosynthetic rate. The results of our study are in accord with the results of ZHANG et al. (2007) and Ali et al. (2008) who reported a decrease in Chl concentrations due to high concentrations of aluminum.

\section{Conclusions}

The application of different concentrations of Al into the culture medium of the date palm produced significant effects on some growth criteria, $\mathrm{AlCl}_{3}$ treatment at an amount of $50 \mathrm{mg} \mathrm{l}^{-1}$ stimulated the development of callus, with high differentiation percentage of shoots and an increasing number of shoots differentiated. Additionally, the shoots were found to have higher contents of potassium, magnesium, sodium, and chlorophyll when they were grown under this level compared to the other treatments. On the other hand, Al treatment at a concentration of 100 $\mathrm{mg} \mathrm{l}^{-1}$ stimulated the proline accumulation with increasing the activity of APX.

\section{References}

Ali, B., Hasans. A., Hayats, Q., Yadv, S., Fariduddin, Q., Ahmed, A., 2008. A role for brassinosteroids in the amelioration of aluminium stress through antioxidant system in mung bean. Environmental and Experimental Botany, 62: $153-159$.

Al-Mayahi, A.M.W., Ahmed, A.N., Al-Khalifa, A.A., 2010. Isolation and diagnose of fungi associated with the cultivation of tissues of five cultivars of date palm (Phoenix dactylifera L.) and the effect of fungicide Benlate in control. Basra Journal for Date Palm Research, 9 (2): 79-97.

Al-MaYAhI, A.M.W., 2012. Effect of the media on vegetative buds and rooting of vegetative shoot of date palm cv. Khadrawi propagated by in vitro culture. Journal of Agricultural and Veterinary Sciences, 5 (1): 27-46.

AL-MaYAHI, A.M.W., 2014. Effect of copper sulphate and cobalt chloride on growth of the in vitro culture tissues for date palm (Phoenix dactylifera L.) cv. Ashgar. American Journal of Agricultural and Biological Sciences, 9 (1): $6-18$.

Al-MaYahi, A.M.W., 2015. The compound effects of $\mathrm{NaCl}$ and gibberellic acid on the growth and development of in vitro date palm (Phoenix dactylifera L.) plantlets cv. Showathy. Journal of King Saudi University Agricultural Science, 26 (2): 147-183.

AL-MaYAHI, A.M.W., 2016 a. Effect of red and blue light emitting diodes "CRB-LED" on in vitro organogenesis of date palm (Phoenix dactylifera L.) cv. Alshakr. World Journal of Microbiology and Biotechnology, 32: 160.

AL-Mayahi, A.M.W., 2016b. Effect of silicon (Si) application on Phoenix dactylifera L. growth under drought stress induced by polyethylene glycol (PEG) in vitro. American Journal of Plant Sciences, 7: 1711-1728.

AL-MAYAhI, A.M.W., 2016c. Influence of salicylic acid (SA) and ascorbic acid (ASA) on in vitro propagation and salt tolerance of date palm (Phoenix dactylifera L.) cv. 'Nersy'. Australian Journal of Crop Science, 10 (7): 969-976.

Al-Khalifah, R., Manickavsagan, A., 2012. An overview of date palm. In Manickavasagan, A., Mohamed, E.M., SUKUMAR, E. (eds). Dates, production, processing, food and medicinal values. Florida, FL, USA: CRC Press, p. 3-11.

Amaral, J.A.T., Rena, A.B., Cordeiro, A.T, Schmildt, ER., 2013. Effects of aluminum, nitrate and ammonium on the growth, potassium content and composition of amino acids in Stylosanthes. Idesia, 31 (2): 61-68.

Ashraf, M., Foolad, M.R., 2007. Roles of glycine betaine and proline in improving plant abiotic stress resistance. Environmental and Experimental Botany, 59: 206-216.

Basso, L.H.M., Lima, G.P.P., Goncalves, A.N., Vilhena, S.M.C., PADilha, C. do C. F., 2007. Efeito do aluminio no contedo de poliamin a slivrese atividade da fosfatase acidadurante o crescimento debrotaçes de Eucalyptus grandis $x$ E. urophylla cultivadas in vitro [Effect of aluminium on the tree polyamines content and acid phosphatase activity during the growth of Eucalyptus $\times$ E. urophylla shoots cultivated in vitro]. Scientia Forestalis, 75: 9-18. 
Bates, L.S., WaldRen, R.P., Teare, I.D., 1973. Rapid determination of free proline for water-stress studies. Plant and Soil, 39: 205-207.

Black, C.A., 1965. Methods of soil analysis. Part 1, Physical and mineralogical properties, including statistics of measurement and sampling. Agronomy, vol. 9. Madison, Wis.: American Society of Agronomy. 770 p.

Chao, C.T., Krueger, R.R., 2007. The date palm (Phoenix dactylifera L.): overview of biology, uses, and cultivation. Horticultural Science, 42: 1077-1082.

Cresser, M.S., Parsons, J.W., 1979. Sulphuric perchloric acid digestion of plant material for the determination of nitrogen, phosphorus, potassium, calcium and magnesium. Analytica Chimica Acta, 109: 43-436.

Ezaki, B., Suzuki, M., Motoda, H., Kawamur, M., NaKashima, S., Мatsumoto, H., 2004. Mechanism of gene expression of Arabidopsis Glutathione S-transferase, AtGST1 and AtGST11 in response to aluminum stress. Plant Physiology, 134: 1672-1682.

Gueye, B., Morcillo, F., Collin, M., Gargani, D., Overvoorde, P., Bertossi, F.A., Taranbarger, T.J., SANe, D., Tregear, J.W., Borgell, A., Verdeil, J.L., 2009. Acquisition of callogenic capacity in date palm leaf tissues in response to 2,4-D treatment. Plant Cell, Tissue and Organ Culture, 99: 35-45.

Hossian, Z., Mandal, A.K., DatTa, S.K., 2006. Development of $\mathrm{NaCl}$ tolerant strain in Chrysanthemum morifolium Ramat. Through in vitro mutagenesis. Plant Biology, 8: 450-461.

Hussian, K., Sahadevan, K.K., Salim, N., 2010. Bioaccumulation and release of mercury in (Vigna mungo L.) hepper seedlings. Journal of Stress Physiology \& Biochemistry, 6 : $56-63$.

Jasim, A.M., Al-Mayahi, A.M.W., Aтtaha, A.H.M., 2009. Propagation of four rare cultivars of date palm (phoenix dactylifera L.) by tissue culture techniques. Basrah Journal for Date Palm Research, 8 (1): 72-99.

Jemo, M., Abaidoo, R.C., Notle, C., Horst, W.J., 2007. Aluminum resistance of cowpea as affected by phosphorus-deficiency stress. Journal of Plant Physiology, 164: 442-451.

Kalaji, H.M., Jajoo, A., Oukarroum, A., Brestic, M., ZivCaK, M., Samboska, I.A., Cetner, M.D., ŁukasiK, I., Goltsev, V., Ladle, R.J., 2016. Chlorophyll a fluorescence as a tool to monitor physiological status of plants under abiotic stress conditions. Acta Physiologiae Plantarum, 38 (4): 102-113.

Koca, H., Bor, M., Ozdemie, F., Turkan., I., 2007. The effect of salt stress on lip peroxidation, antioxidative enzymes and proline content of sesame cultivars. Environmental and Experimental Botany, 60: 344-3

MA, J.F., 2007. Syndrome of aluminum toxicity and diversity of aluminum resistance in higher plants. International Review of Cytology, 264: 225-252.

Malavolta, E., Vitti, G.C., Oliveira, S.A., 1997. Avaliaço do estado nutricional das plantas: principos e aplicaçes. [Assessment of nutritional status of plants: principles and applications]. 2.ed. Piracicaba: Potafos. 319p.

MARSCNER, H., 1995. Mineral nutrition of higher plants. London: Academic Press. 674 p.

Meriǹo-Gergichevich, C., Alberdi, M., Ivanov, A.G., Reyes-DiAZ, M., 2010. $\mathrm{Al}^{3+}-\mathrm{Ca}^{2+}$ Interaction in plants growing in acid soils: Al-phytotoxicity response to cal- careous amendments. Journal of Soil Science and Plant Nutrition, 10: 217-243.

Munnē-Bosch, S, Jubany-Mari, T., Alegre, L., 2001. Drought-induced senescence is characterized by loss of antioxidant defences in chloroplasts. Plant Cell and Environment, 24: 1319-1327.

Murashige, T., Skoog, F., 1962. A revised medium for rapid growth and bio assays with tobacco tissue cultures. Physiologia Plantarum, 15: 473-497.

MuRPhy, T., RiLEY, J.R.J., 1962. A modified single solution method for the determination of phosphate in natural waters. Analytica Chimica Acta, 27: 31-36.

NAKANO, Y., AsAdA, K., 1981. Hydrogen peroxide is scavenged by ascorbate-specific peroxidase in spinach chloroplasts. Plant and Cell Physiology, 22: 867-880.

Page, A.L, Miller, R.H, Keeny, D., 1982. Methods of soil analysis. Part 2. Madison, Wis.: American Society of Agronomy.

Porra, RJ., 2002. The chequered history of the development and use of stimulation quantions for the accurate determination of chlorophylls a and b. Photosynthesis Research, 73: 149-156.

Ribeiro, M.A.Q., De AlmeidaA, A.-A.F., Mielke, M.S., Gomes, F.P., Pires, M.V., Baligar, V.C., 2013. Aluminum effects on growth photosynthesis, and mineral nutrition of cacao genotypes. Journal of Plant Nutrition, 36: 8: 1161-1179.

Rout, G.R., Samantaray, S., Das, P., 2001. Aluminium toxicity in plants: a review. Agronomie, 21: 3-21.

Rufyikiri, G., Dufey, J.E., Nootens, D., Delvaux, B., 2000. Effect of aluminium on bananas (Musa spp.) cultivated in acid solutions. II. Water and nutrient uptake. Fruits, 56 (1): 5-16.

Siripornadulsil, S., Train, S., Verma, D.P.S., Sayre, RT., 2002. Molecular mechanisms of proline-mediated tolerance to toxic heavy metals in transgenic microalgae. Plant Cell, 14: 2837-2847.

TAIZ, L., ZeIGER, E., 2009. Fisiologia vegetal [Plant physiology]. 4. ed. Porto Alegre: Artmed. 819 p.

Uhrin, P., Supuka, J., Billikova, M., 2018. Growth adaptability of Norway maple (Acer platanoides L.) to urban environment. Folia Oecologica. 45 (1):33-45.

Vardar, F., Arican, E., GöZüKIRIZI, N., 2006. Effect of Aluminum on in vitro root growth and seed germination of tobacco (Nicotiana tabacum L.). Advances in Food Sciences, 28 (2): 85-88.

Yousefi, S, Kartoolinjad, D., Bahmani, M., Naghdi, R., 2017. Salinity tolerance of Dodonaea viscosa L. inoculated with plant growth-promoting rhizobacteria: assessed based on seed germination and seedling growth characteristics. Folia Oecologica, 44 (1): 20-27.

Zayed, Z.E., Eldawayati, M.M., Elsharabasy, S.F., 2019. Total steroids production from date palm callus under heavy metals stress. Biological Research, 16 (2): 14481457.

Zhang, X.B., Peng, L., Yang, Y.S., Xu, G.-D., 2007. Effect of $\mathrm{Al}$ in soil on photosynthesis and related morphological and physiological characteristics of two soybean genotypes. Botany Study 48: 435-444.

Received July 7, 2019 Accepted November 12, 2019 